\title{
The earliest portrait of St Columba: Cod Sang 555, p 166
}

\author{
Jane Geddes ${ }^{1}$
}

\begin{abstract}
The portrait of St Columba was made on the last page of a version of The Life of St Columba by Adomnán. The book, Cod Sang 555, was written at the monastery of St Gallen in the later 9th century and the drawing possibly added shortly afterwards. The image shows Columba both on a mountain and inside a church, both alive with hands raised in prayer and dead, represented by his adjacent reliquary. The shape of the reliquary is matched by an illustration of the Ark of the Covenant, made at St Gallen at about the same time. This reveals the meaning of the picture: as God spoke to his people from the mercy seat on the Ark of the Covenant, Columba speaks directly to his reader and devotees through his relics in the shrine. It is proposed that the smaller container beside the reliquary is a satchel, possibly for containing this book itself. Typological exegesis relating the Old Testament to Columba explains Columba's mystical appearance simultaneously on the mountain and in a church; and his ability to appear in person after his death. The concept of praesentia accounts for his active role as intercessor for his followers. The picture was composed at a time when illustrated saints' lives were beginning to develop with detailed narrative sequences. This image stands apart because it does not illustrate events from the accompanying text. The text of Cod Sang 555 had already excised details of Columba's Irish/ Scottish background on Iona to make it more relevant to a continental audience. Likewise, this image places Columba, through the power of his relics, no longer on Iona but directly before his followers in St Gallen Abbey.

All manuscript comparisons are digitally available, with their URL in the references.
\end{abstract}

The simple pen and ink sketch shows St Columba, hands raised in prayer (Illus 1). Although he stands under an arch, presumably within a building, his feet rest on a heap of rocky boulders and grasses. On the right is a piece of furniture on which are placed two small containers. Two inscriptions indicate that this is St Columba. One is written in display capitals contemporary with the sketch: SCOLVMBA. The other, Scs Coluba, is in a script of c 1200 (Cod Sang 555). ${ }^{1}$ This image, perhaps a later addition to the book, was drawn on the last verso of Cod Sang 555, p 166, a version of Adomnán's Life of St Columba, written at St Gallen in the third quarter of the 9th century. The portrait seems so simple, even unfinished, but it is loaded with profound spiritual meaning. It says little about the subject of the text, Columba's life at Iona in the 6th century, but it is a mine of information about the cult of St Columba in the late 9th or early 10th century at St Gallen in present-day Switzerland. This article provides an art historical supplement to the discoveries published by Peter Yeoman (2016: 153-65) who studied the image from an archaeological point of view, and focused on the shrine of Insular appearance - which is depicted on the right of the picture. Each component part of the composition will be examined in turn, in order to explain the meaning and purpose of the picture. A brief history of the text is followed by an analysis of the figure style, the location, and furnishings. This leads to an examination of what St Columba might be doing, and why he is doing it at St Gallen.

\footnotetext{
1 j.geddes@abdn.ac.uk
} 


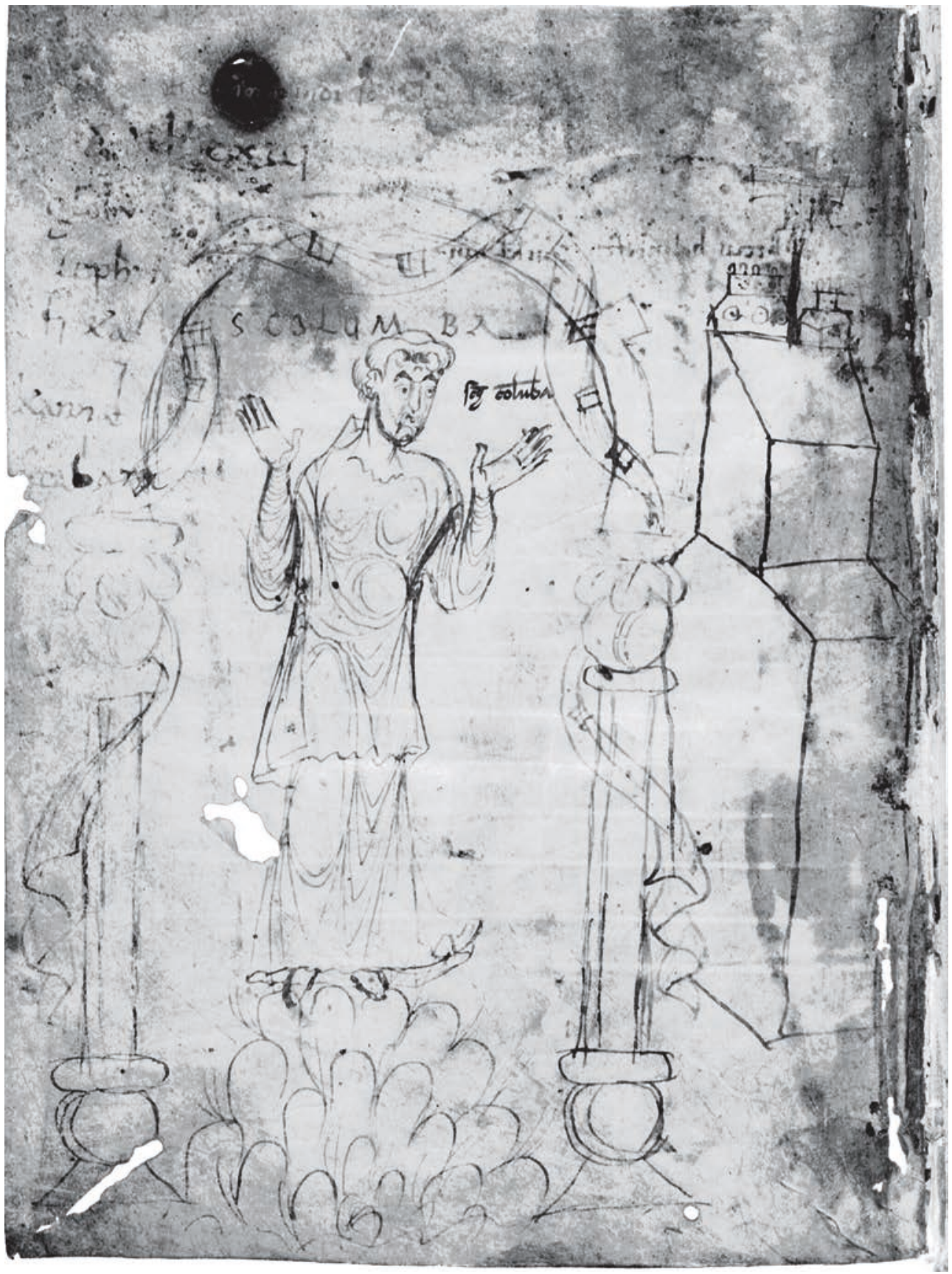

Illus 1 St Columba, third quarter of the 9th century, Cod Sang 555: Vita sancti Columbae, p 166. Digitally enhanced. (@ Stiftsbibliothek St Gallen) 
St Columba died on Iona in 597 and his Life was written by his follower Adomnán, ninth abbot of Iona (679-704). The occasion for writing the book may have been the centenary of the saint's death, in 697 (Sharpe 1995: 53-5). Adomnán mentions that Columba's sanctity was venerated abroad, reaching the 'three corners of Spain, Gaul and Italy beyond the Alps, and even Rome' (Sharpe 1995: III-23). The Irish missionary Columbanus ( $c$ 543-615), from Bangor, brought the austere religious precepts of Columba to the Continent, founding monasteries at Annegray, Luxeuil, Fontaines and Bobbio. When Columbanus moved on to Bobbio in 614 , his Irish companion Gall (died $c$ 630) stayed behind to live in a hermitage which ultimately ( $c 719)$ became the Benedictine monastery of St Gallen, close to Lake Constance (Farmer 1980). Among the books carried abroad by Irish missionaries was the earliest surviving text of Adomnán's Life of St Columba, created by Abbot Dorbbéne in the Iona scriptorium $c 700$, originally held at

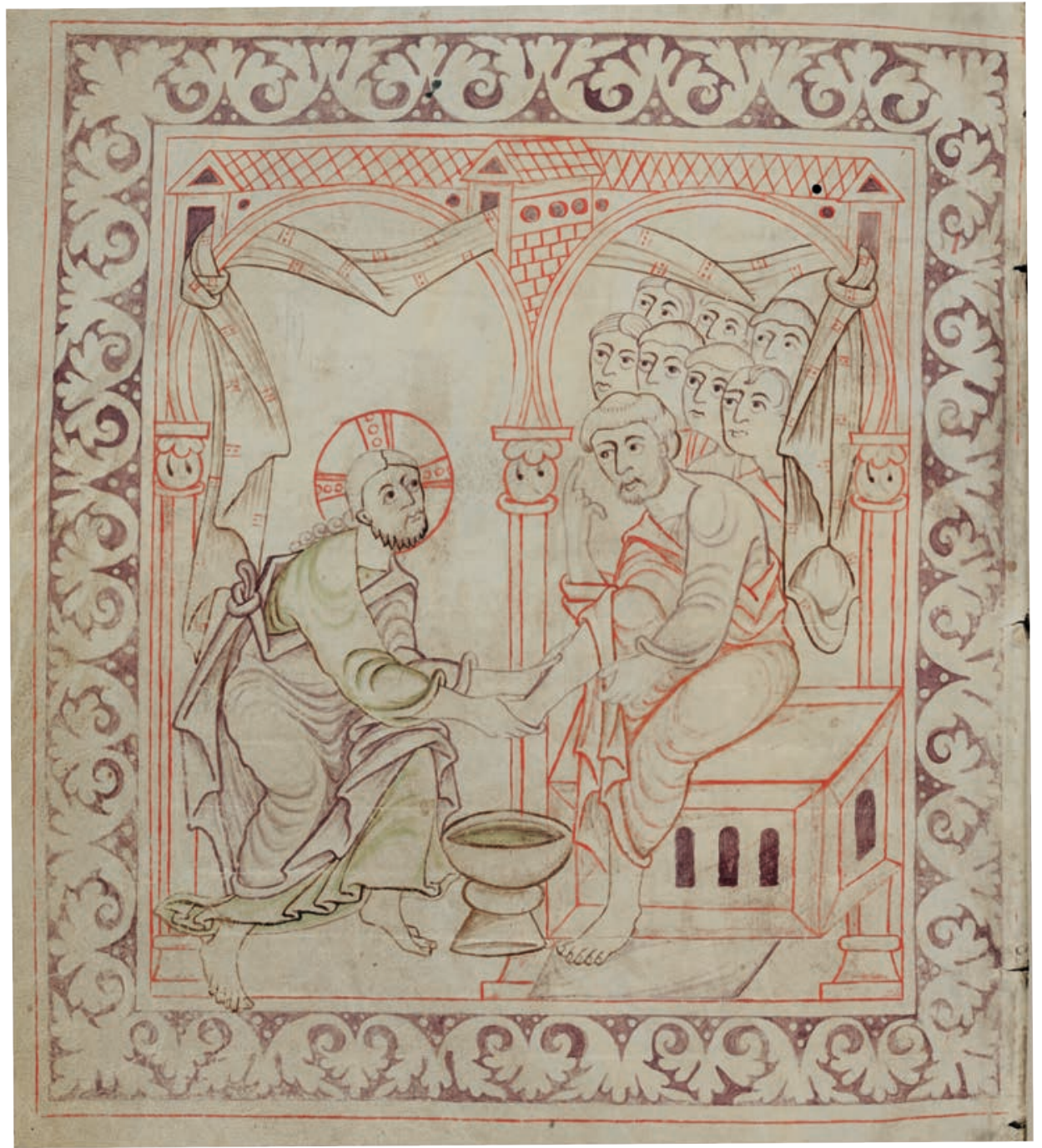

Illus 2 Hartker Antiphonary, 990-100, Cod Sang 390: Antiphonarium officii, p 186. (@ Stiftsbibliothek St Gallen) 
the monastery of Reichenau on Lake Constance, near St Gallen (Schaffhausen Stadtbibliothek, Gen 1). This text is conventionally designated as MS A (Sharpe 1995: 236) and is considered to be the source of all the continental versions, possibly having arrived in the 8th century via the monasteries of Péronne and Fosses in northern France, which were part of the familia of monasteries related to the Irish saint Fursa (Picard 1998: 4). MS A reached Reichenau $c$ 850, and soon after was copied at St Gallen, in the third quarter of the 9th century (Cod Sang 555). This new continental version makes considerable cuts to the original text, removing episodes specific to the Irish context, proper names and geographical data, while retaining chapters with universal appeal for the edification of the St Gallen monks (Picard 1998: 9). ${ }^{2}$

\section{STYLE AND ATTRIBUTES OF THE DRAWING}

The figure style is light and animated. Drapery flutters in soft nested circular and V-folds. Distinctive features on Columba's face are his curled ears, bold and emphatic eyebrows, large eyes, nose with a drop on its tip, and mouth with downward-slanting lines on each side. Faces in the Folchart Psalter, made at St Gall between 872 and 883, apply similar conventions, a clear example shown on the right on p 7 (Cod Sang

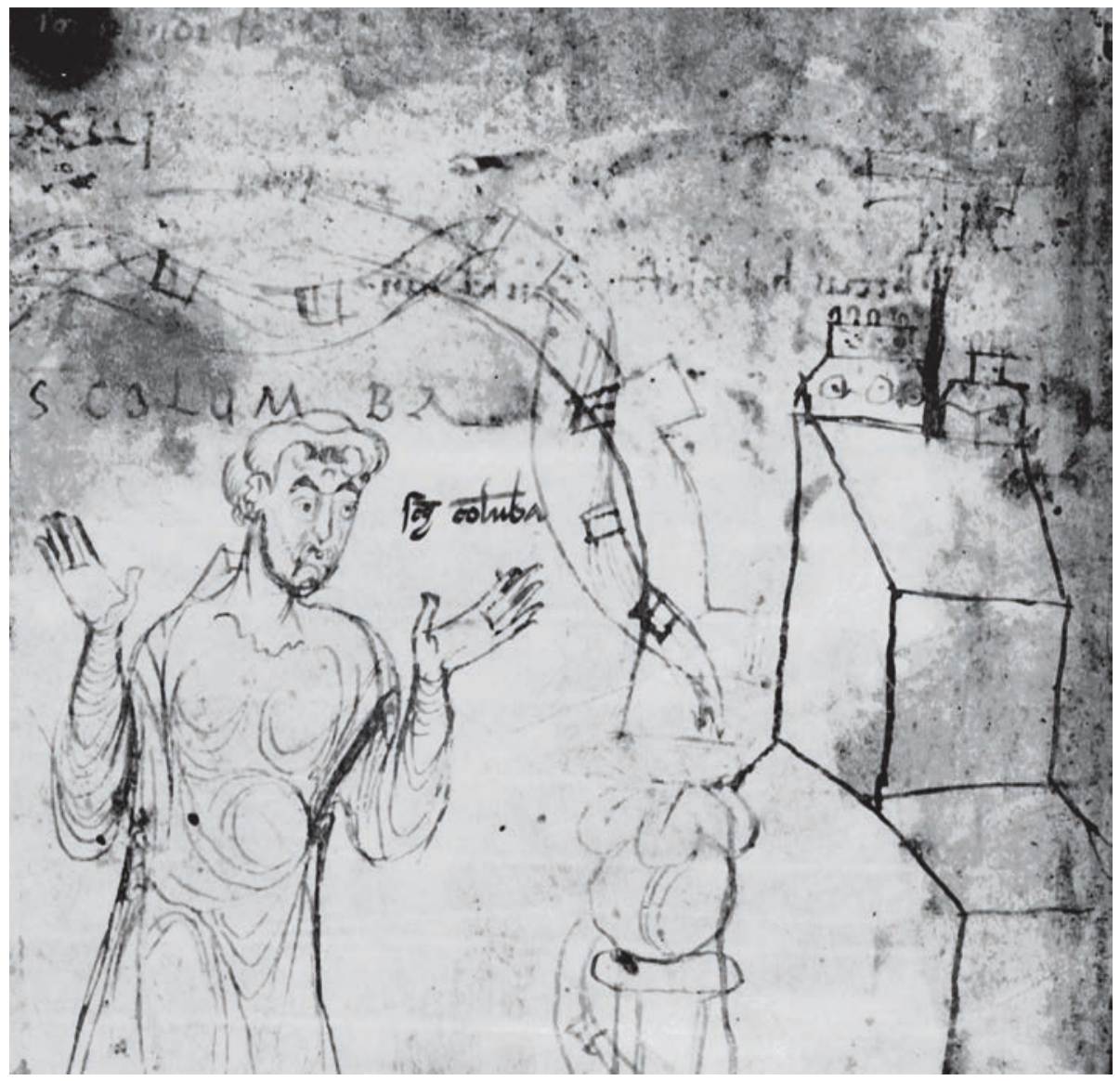

Illus 3 St Columba. Detail, digitally enhanced. Cod Sang 555, p 166. (C Stiftsbibliothek St Gallen) 
23). A similar type of soft drapery can be seen in the Golden Psalter of St Gall, p 2 and p 150 (Cod Sang 22). This part of the psalter was made around 883-8. However, a century later these same conventions, including nested drapery folds albeit with a harder outline, are still employed at St Gallen, in the Hartker Antiphonary of $c 990$ 1000, p 13 and p 186 (Cod Sang 390) (Illus 2).

The same date range can be found for the architectural features (Illus 1, 3). The arch has a base consisting of a truncated triangle, a circle and a bulging torus. The column is polygonal. The capital has a plain necking and is circular, topped by some drooping foliage forms expressed in hanging loops. The arch is slightly horseshoe shaped. The voussoirs are arranged in a longand-short manner, with alternating stones keyed into the surrounding wall. Around the arch is a fluttering drape, rather like a soft scarf or ribbon, wound loosely around the arch and column. It is decorated by a few small but distinct rectilinear patterns, shaped like the letter E.

Most of these features can be seen on the Folchart Psalter mentioned above, for instance p 9 and p 12 (Illus 4). This includes the shape of the base and capitals, and the horseshoe arch. These are designed as the fictional framing for text. A century later the Hartker Antiphonary (p 186), 990-1000, shows these same features in an architectural context: the bases, the

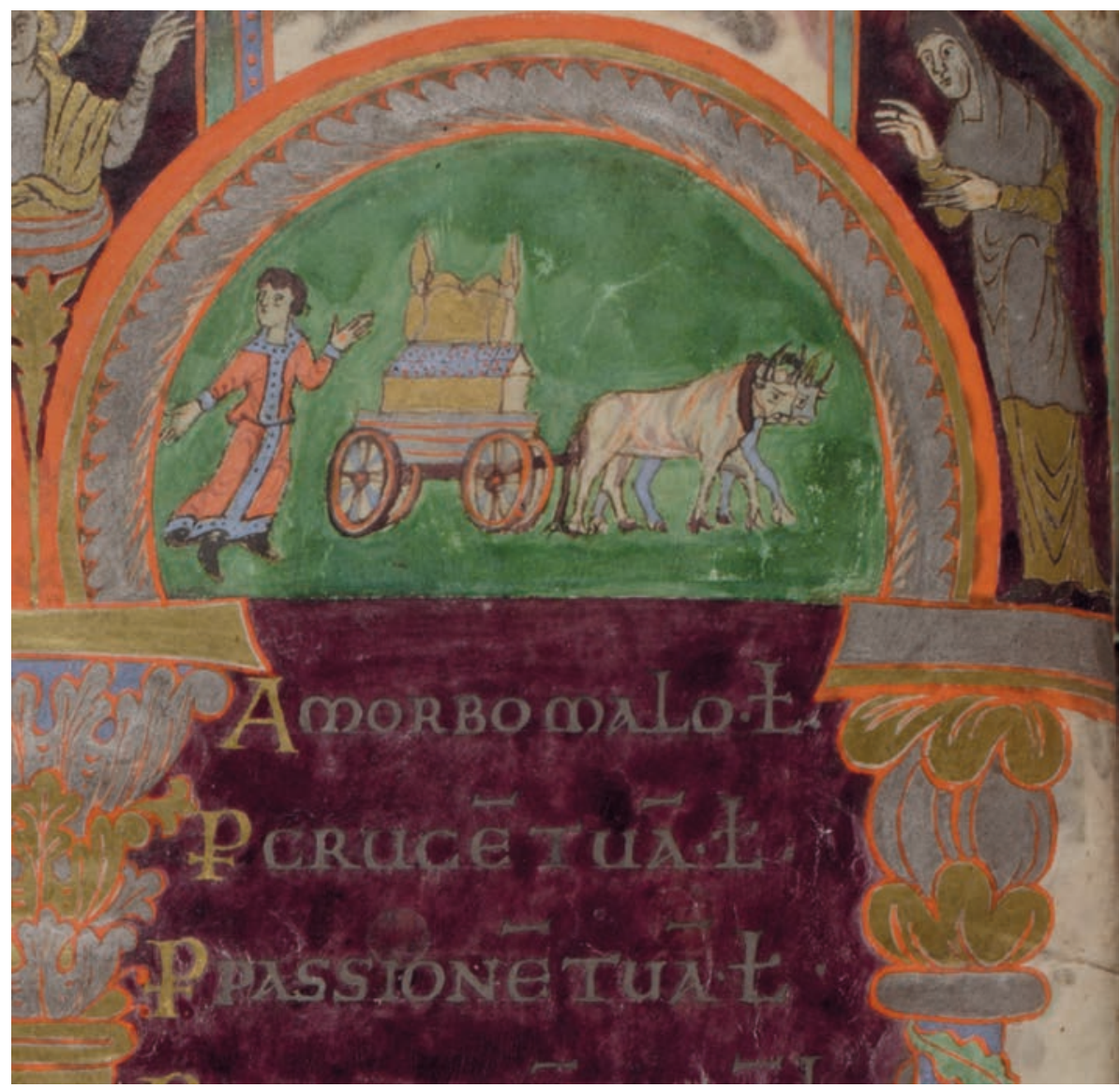

ILLus 4 Folchart Psalter, 872-83, detail showing foliage capitals, horseshoe arch and Ark of the Covenant. Cod Sang 23: Folchart Psalter, p 12. (C) Stiftsbibliothek St Gallen) 
polygonal columns, the drooping leaf capitals, horseshoe arch and curtain embroidered with rectangular motifs (Illus 2). The horseshoe arches are not an indication that this was a motif in Carolingian architecture (Dewald 1922: 336). On the contrary, apart from an unusual example of the chancel arch at Germigny-des-Prés, made in the early 9th century, horseshoe arches are commonly found in Carolingian manuscripts, as a form of ornamental arcade around canon tables, or representing a building as in the Hartker Antiphonary (Illus 2). Examples are in the Lex Romana Visigothorum made in 794 (Cod Sang 731, p 234) and the Codex Aureus of St Emmeram from 870 (Munich, Bayerische Staatsbibliothek, Clm 14000, image 35).

While fluttering drapes no longer twist around church columns, a fragment of marble church furnishing from Chur Cathedral (8th-9th century) shows the twisted cloth around the column carved into stone (Lubke 1965: illus 132, no. 248). Thus stylistic comparisons from within the St Gallen library suggest a date for the image close to the Golden and Folchart Psalters, made between 872 and 888 . This implies the drawing is slightly later than the text itself, which is dated by von Euw to 'third quarter of the ninth century' (2008: 357-8). However, comparisons with the Hartker Antiphonary show similar stylistic features were embedded in the St Gallen scriptorium for another century.

Under Columba's feet is a heap of sketchy oval forms. These are a convention for rocks or boulders on a mountain, as shown by scenes in the Utrecht Psalter (for instance, Utrecht, Universiteetsbibliothek, MS 32, f 3v) and at St Gallen, Cod Sang 855, p 350, Grammatica from the mid-9th century.

For the containers there are close parallels in other media, and they appear to unlock the entire meaning of the picture (Illus 3). Yeoman (2016: 160-1) has remarked on the undoubted similarity between the left box and Insular reliquaries like the Monymusk and Bologna shrines. He makes this connection because both the drawing and these reliquaries are small boxes with a hipped roof adorned with a similar arrangement of roundels. However, these real Insular containers are all topped by a roof-ridge bar with inturned animal head terminals, a different arrangement from the drawing. The drawn container has four sections: a box with three circular ornaments at the base, a hipped roof, another rectangular form with three more roundels and then a schematised crest of four oval 'hoops'. This construction is replicated in the Folchart Psalter, p 12 (Illus 4 ), already mentioned as a close comparison for other aspects of the portrait. The Folchart illustration comes from the Litany and the complete scene shows David collecting the Ark of the Covenant on an ox cart and, in the adjacent arch, playing his harp before the Lord (2 Samuel $6)$. The object consists of a box base with gableend roof. Above this is a rectangle and crest of two 'hoops' and two finials. From this scene, it is clear that the reliquary in our drawing is supposed to resemble, albeit in a schematic way, the Ark of the Covenant as described in Exodus 25:10-21. The Ark itself was an oblong box with two rings, one each side, for lifting with poles. Placed above the Ark was the mercy seat with a cherub at each end, stretching out their wings to cover the Ark. The hoops and finials shown on the crests of the two manuscripts are progressively simplified illustrations of the mercy seat and angels with their wings. The beginnings of such a schematic formula are illustrated in the plan of the Temple in Jerusalem, in the Codex Amiatinus written at Jarrow before 716. This image is likely to be a copy of the plan made by Cassiodorus in the mid-6th century, for his Codex Grandior. It shows the Ark as a square box with a flat top and two oval/lentoid finials representing the cherubim, felicitously described by Bruce-Mitford as 'tapering objects with bifid tops which look like fish standing on their heads' (Bruce-Mitford 1969: 8, 16).

The point about representing the Ark of the Covenant in the Columba drawing is that God announces in Exodus 25:22 'There I will meet with you, and from above the mercy seat, from between the two cherubim that are on the Ark of the Covenant, I will deliver to you all my commands for the Israelites' (NRSV). This particular shape of reliquary therefore facilitates the presence of and communication with the saint himself. Resonance with the Ark of the Covenant and the tabernacle is amplified by the 
conspicuous embroidered curtain which flutters around the arch. Exodus 26:36 describes how the Ark was protected by a hanging in front of the door of the tent, made of fine twisted linen, wrought with needlework. This pictorial interpretation of the Ark of the Covenant does not preclude the existence of an actual Insular casket at St Gallen (pace Yeoman 2016). As with the horseshoe arch, we are looking at an artistic invention, not a photograph.

No shrine in the corpus of early medieval reliquaries illustrated by Quast (2012: Tafel 1-44) has hoops on its ridge (apart from Cat 1.19 , a shrine of unknown provenance in the Getty Museum, Malibu, whose perforated crest consists of open-jawed animals); only the Ennabeuren reliquary (Quast 2012: Tafel 1) has a rectangular panel above the hipped roof, but this panel or crest depicts a man between two beasts. Thus, the unequivocal identity of the Ark of the Covenant, depicted so schematically in the Folchart Psalter and Cod Sang 555, puts these two examples in a separate category from the surviving corpus of house-shaped shrines. The Ark makes a monumental Carolingian appearance in the mosaics of the apse at Germigny-des-Prés, commissioned by Theodulf of Orléans in $c 805$. This gleaming gold illustration is much closer to the description in Exodus. It is a rectangular box with gold rings on each corner supporting golden poles. Cherubim stretch forth their wings appropriately - although before restoration the box appeared to be empty and containing a cloth rather than bearing the mercy seat (Freeman \& Meyvaert 2001: 129-30). More relevant in our case is the reliquary made by Hrabanus Maurus of Fulda Abbey in 835. According to his biographer Rudolph, he placed the bones of several saints "in an ark which he made in the image of the ark of the covenant of God, out of wood and gold, with cherubim and handles'. A further description in the 10th-century Gesta Abbatum of Fulda mentions that every part was covered with gold 'a propitiation, the Cherubim of glory, with a portable candelabrum made of gold. He established the delightful procession of palms and was accustomed to bring out that same ark with its ornaments in great glory' (Appleby 1995: 432-3). This example is helpful because it not only shows the form of the Ark was being used as a reliquary in the 9th century relatively near St Gallen, but also because Hrabanus Maurus explains the exegetical meaning of the Ark in various aspects: 'God the Father speaks from the space between the Cherubim and the Son speaks through the Old and New Testament.' 'Under the Old Covenant, it contained the laws and relics of the Hebrew past; under the new covenant it ... now contains evidence of the new covenant, namely grace.' Hrabanus links the Ark in Jerusalem with the current practice of processions and performance of the mass at Fulda (Appleby 1995: 436-8). This exegesis is significant firstly because most of it derives from De Institutione Clericorum, a teaching manual written by Hrabanus Maurus in 819, where he expounds on the Ark of the Covenant, past, present and through eternity. A copy of this text, made around 850, arrived at St Gallen probably under Abbot Grimald (841-72) (Appleby 1995: 436; Cod Sang 286). Secondly, Hartmut, the abbot of St Gallen (872-83) who commissioned the Folchart Psalter with its illustration of the Ark, had previously been a pupil of Hrabanus Maurus at Fulda, so he would have known both about the golden reliquary and its meaning (Duft 1969; Cod Sang 023).

Yeoman suggests the right container could be another house-shaped shrine $(2016: 158,162)$ but it is slightly different (Illus 3 ). It is smaller and plain. It appears to have a carrying handle above and a V-shaped flap on the side. Projecting on its upper edge are three small loops, similar to those on the adjacent casket. This is more like a leather satchel, like those covering Oxford, Corpus Christi College MS 282, and the Book of Armagh (Meehan 2005: 86, 88) (Illus 5). If this is indeed a satchel rather than a simplified shrine, then the loops on top are remarkably like the additional ties attached to the Oxford example. These satchels, known in Latin as theca, could be used for carrying books or reliquaries. They were an essential part of clerical equipment, sometimes of a highly personal nature. Walahfrid Strabo, writing the Life of St Gall (before 837), mentions the patron saint of the abbey had a 'case made of leather' which he slung over his shoulder: it was locked and St Gall never allowed anyone to 


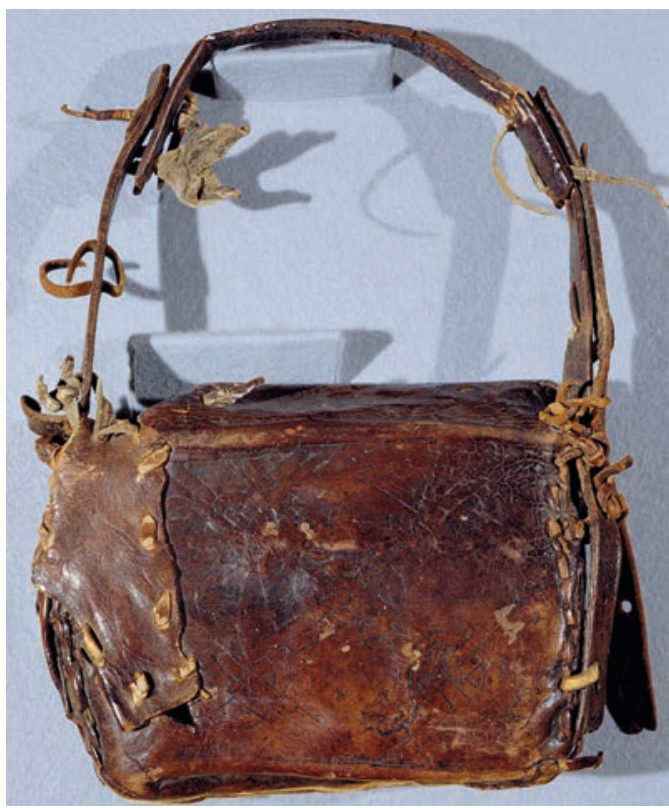

ILlus 5 Satchel for MS 282, Corpus Christi College, Oxford, 12th century. (¿ Corpus Christi College, Oxford, UK/Bridgeman Images)

look at its contents. After his death, the monks found it contained a hair shirt and chain, both stained with blood from where they had chafed the saint's flesh (Joynt 1927: 109). A homily on the life of St Columba from the Leabhar Breac (c 1394) says that St Columba personally made satchels and wallets for books and all church equipment. The opportunity for an Irish theca to turn up at St Gallen can be mirrored by a tale from the 10th-century Tripartite Life of St Patrick. Patrick met a group of clerical pilgrims on their way to Rome, carrying books on their belts, and offered them skins to make satchels (quoted in Stokes 1877: 115; Stokes 1887: 75; Meehan 2005: 87).

This satchel could simply be the container for the adjacent reliquary but it would be a tight fit. Wormald suggests an intriguing alternative. $\mathrm{He}$ reflects on the function and status of the illustrated saints' lives: the libellus was often a special book not under the jurisdiction of the librarian but of the sacristan, kept in the treasury not the library, like part of the title deeds of the monastery, 'perhaps only a little less important than the shrine itself' (Wormald 1988: 52). So quite possibly the little satchel could be the container for this very volume with its illustration of Columba, the essential adjunct to his relics.

Photography with enhanced contrast reveals that between the containers is a processional cross (Illus 3). It has a vertical black shaft, arms of equal length with slightly splayed terminals and a medial line forming an internal linear cross. It would have accompanied the containers when they were carried around the church or district for festivals. Such a procession, linking our three items of shrine, satchel and cross, is mentioned in the Miracula of St Columbanus at Bobbio, in 929. The saint's bones were placed in a casket. The procession was preceded by priests carrying hand bells, crosses, candles and incense. Along with the casket were the cup (cuppa) and satchel (pera) in which Columbanus had carried his gospels (Richter 2008: 177, quoting Bresslau 1932: chapter 11, p 1003).

The precise nature of the stand is important because it tells us where the reliquaries are located within the church (Illus 3). It appears to be a tall rectangular box-like base, with a smaller box on top with a sloping face. Such a construction would be comparable to the late 10th-century lectern shown in the Registrum Gregorii (Trier, Stadtbibliothek, HS171/1626, Gregory leaf) but a lectern ledge would neither be suitably safe nor prestigious enough to house reliquaries. The St Gallen Psalter, made 820-30, provides a reasonable explanation (Zurich Zentralbibliothek, MS C 12, f 53r). It shows the earliest image of an altar produced by the St Gallen scriptorium and the structure is conveniently covered with a cloth (illustrated in Yeoman 2016: 163). It shows a rectangular base with the appearance of a lectern shape on top, but of course the sloping plane of the altar top is due to the perspective. I would therefore suggest our image is actually showing a flat-topped altar with an additional plinth at the back to raise the reliquaries above the altar surface.

The spatial relationship between an altar and a reliquary was crucial, particularly in the 8th to 10th centuries. Crook discusses the position of relics in four places. First was under the altar, where a church was subsequently built over the grave of 


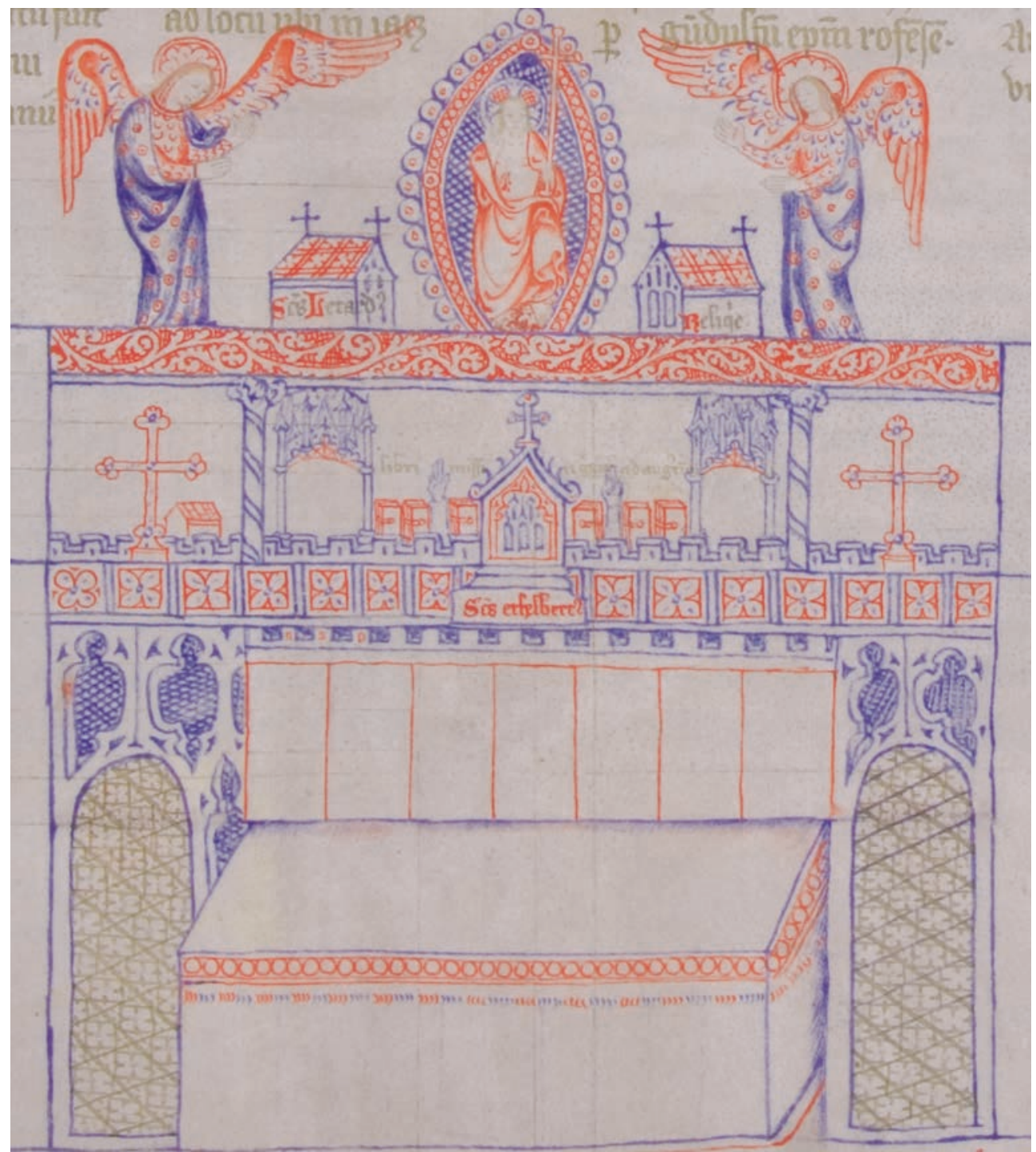

ILlus 6 The altar at St Augustine's Abbey, Canterbury, in 1410-13. Detail showing relics, crosses and books above the altar. Thomas of Elmham, Historia Abbatiae S. Augustini, Cambridge, Trinity Hall, MS 1, f 77a. (@ The Master and Fellows of Trinity Hall, Cambridge)

a saint. Second was within the altar. Here small relic fragments were placed within recesses in the altar. In 801 and 813 Charlemagne re-enacted the decree of the Council of Carthage of 401, insisting that all altars be furnished with relics, a requirement which led to the proliferation of relic fragments (Crook 2000: 13, 67). Inventories from St Gallen of the 9th and 10th centuries indicate that the abbey was richly provided with these relics which included major apostolic saints and early Christian martyrs - Roman as well as Germanic and Irish saints. Records show where these relics were located, Columba being usually mentioned in company with Columbanus. So, in the capsella (coffer) of St Gall himself, in the 9th century, there were relics of many eastern saints, 
but also Patrick, Columba, and 'Congell the teacher of Columbanus and Gall' (Stückelberg 1902-8: II, 3, para 1973). In the Benedict altar were Benedict, Columbanus and Columba, along with many others (Stückelberg 1902-8: II, 4 para 1976). In the inner altar of the Salvator church at St Gallen were Columba together with Benedict, Columbanus and Gall, plus relics of the holy crib, and New Testament figures (Stückelberg 1902-8: II, 6, para 1986). In the altar to the Virgin Mary, in the abbey choir, Columba's remains were found with Gall and Brigit (Stückelberg 1902-8: II, 8, para 1990). By the 10th century, his relics were also to be found within the golden cross in the abbey choir, together with Benedict, Bede, Columbanus and a multitude of other Roman and northern saints (Stückelberg 1902-8: 6-8, para 1989). Among the many inventories, there is no record of Columba's relics uniquely placed in their own casket.

Placing reliquaries upon the altar itself was a temporary solution. By the early 10th century, Odo of Cluny was noticing that relics placed on an altar were less efficacious in achieving cures. This was because on the Lord's altar 'only the dignity of the divine mystery should be celebrated'. St Walburgh herself revealed that her miracles could not continue while her relics remained on the altar (Odo of Cluny, quoted in Crook 2000: 68). However, reliquaries on altars continue to be illustrated as in the 11th-century Bayeux Tapestry and the 12th-century wall painting from the Morley Library in Winchester Cathedral (MacLeod 2011; Winchester Cathedral 2018; John Crook pers comm). The fourth solution was to place the relics above and behind the altar. On the Trinity Chapel glass at Canterbury Cathedral, the reliquary is raised up behind the altar on a columnar stand (Trinity Chapel glass). This is the same arrangement for the shrine of St Ursula at Cologne Cathedral (Bagnoli et al 2011: 21, fig 15). The 15th-century drawing of St Augustine's Abbey (Cambridge, Trinity Hall, MS 1, f 77a) shows an altar clear of clutter but above it on a shelf are the six books sent from Pope Gregory the Great to St Augustine in the 6th century (Illus $6)$. They share the space with two crosses and the shrine to St Ethelbert (560-616), King of Kent and St Augustine's first convert in England. This combination of shrine, books and crosses on a substantial shelf above the altar at Canterbury provides an appropriate parallel for the St Gallen arrangement.

While discussing the relationship between an altar and its relics, it is impossible to ignore the St Gall plan (Cod Sang 1092). This is an idealised diagram of the perfect Carolingian Benedictine establishment, created for Abbot Gozbert between 819 and 830, but excavations show that it does not accurately reflect the real church (St Gall Plan 2012 Architecture). Although the inventories cited above show St Gallen had relics of St Columba, he is not given his own altar on the St Gall plan, possibly because the relics had not yet arrived by 830 (Illus 7). Our image may nonetheless imply St Columba's status within the hierarchy of saints. The church itself is conceived as a vessel for containing as many altars as possible, all arranged in a logical hierarchy (Freeman 2011: 72-3). It focuses on Paul and Peter at the east and west ends respectively, with the centre of the chancel dedicated to St Gall and Mary. Next in the hierarchy come St Benedict and St Columbanus, flanking the chancel arch to north and south. They represent the Roman and Irish heritage of the monastic tradition. It may be significant therefore that in the drawing $\mathrm{St}$ Columba stands by an arch, with the altar to his left or south side, notionally in a similar location to the altar of St Columbanus on the plan. In our drawing, Columba is perhaps being venerated as the progenitor of Columbanus, founder of the monastery's Irish heritage and notionally separated from St Gall himself by only three degrees of pupil and master (Yeoman 2016: 155). Notker Balbulus concludes his account of Columba by articulating this spiritual lineage between St Gall and Columba, showing that the bonds were still close in the 890s when the Life was written (Notker, Martyrologium, June 9, para 11; Picard 1998: 9). Contradicting the idealised plan, inventories indicate the actual altar to Columbanus was directly beneath that of Gall, in the crypt, while Columba's relics were in the altar of St Benedict (on the north side), and in the Mary altar in the choir (Stückelberg 1902-8: II, 4, para 1975, 1976, 1990). 


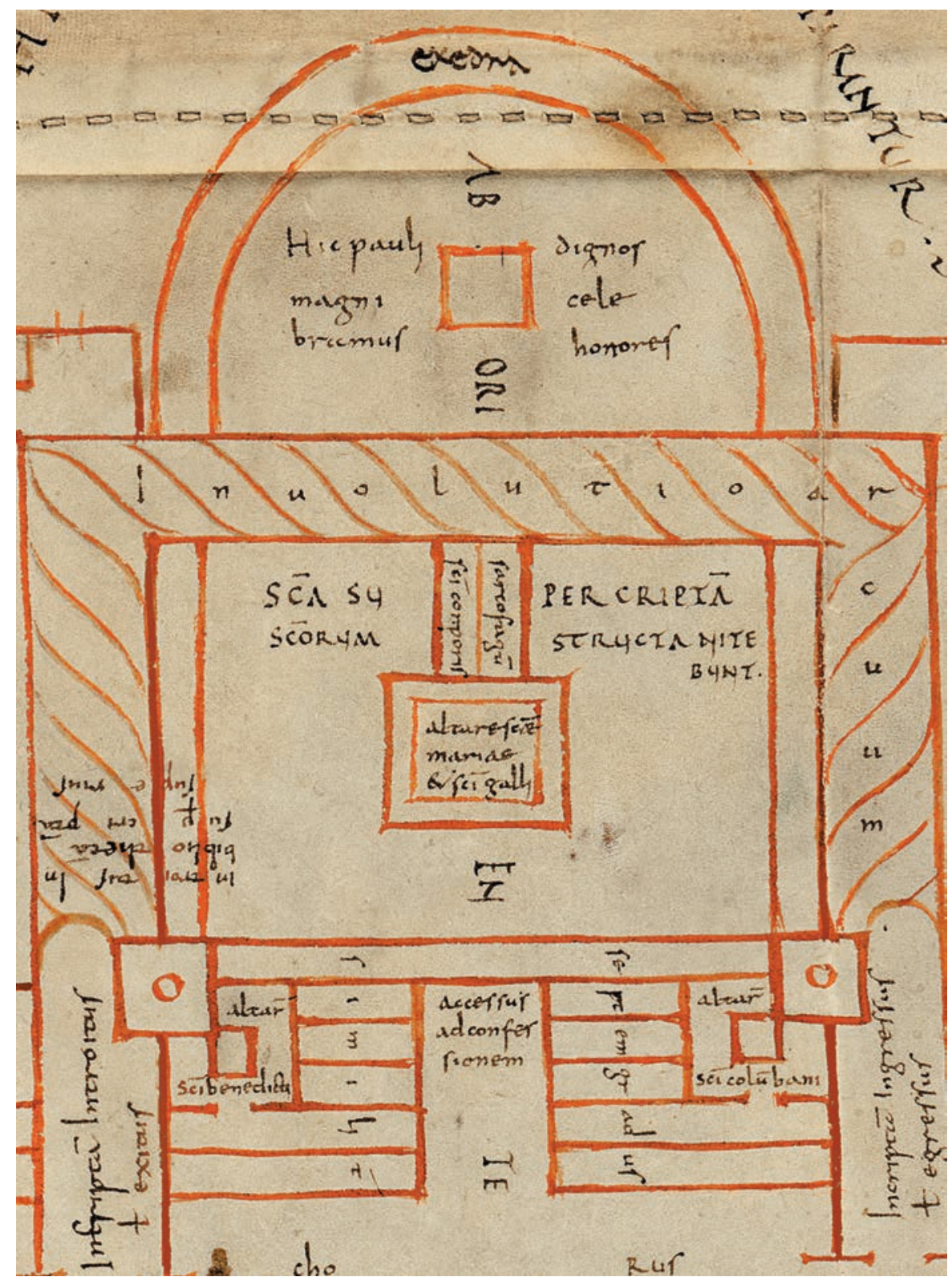

ILLus 7 Plan of Saint Gall, detail of east end of church, 819-30. Cod Sang 1092. The altar of Columbanus is lower right, beside the south-east crossing pier (@ Stiftsbibliothek St Gallen)

Compared with the wide continental distribution of his cult in medieval Europe, named relics of Columba of Iona (not to be confused with Columba of Sens) only cluster in a few places (Picard 1998: 3, 10, 19). Picard mentions St Gallen, possibly with nearby Pfäfers, and Hirsau with nearby Schwäbisch Gmünd. To these may be added St Maurice d'Agaune, Switzerland, which has a parchment fragment used to wrap relics inscribed with Columba's name (Smith 2015: 241). No early Insular sources refer to the transport of Columba's relics abroad; they focus 
instead on the movement of Columba's bones and associated artefacts between Iona, Scotland and Ireland (Bannerman 1993: 14-17). So it may be more than coincidence that the first written mention of Columba's shrine on Iona comes not from Insular sources but from Walahfrid Strabo, abbot of Reichenau Abbey, nearby on Lake Constance (Anderson 1990: I, 263-5). ${ }^{3}$ Before his death in 849 he wrote a poem, apparently from an eyewitness account, of the heroic monk and martyr Blathmac, killed during a Viking raid on Iona in 825 . Walahfrid is the first person to describe the glorious shrine and its concealment before the attack. If Walahfrid's witness travelled from Iona to St Gallen, sometime between 825 and 849 , he might also have carried, not Columba's bones, but a personal object or brandea of some sort, a touch-relic perhaps created during the traumatic concealment of the shrine. Although he was based at Reichenau, Walahfrid is more likely to have picked up the story from St Gallen, given the close Irish contacts of that abbey. As mentioned above, Columba's relics are recorded already at St Gallen in an inventory of the 9th century (Stückelberg 1902-8: para 1973). Such a treasure could account for the subsequent interest in rewriting Columba's life at St Gallen. While teaching at Fulda, Walahfrid Strabo and Hrabanus Maurus created a clerical and academic network which may account for the distribution of Columba's continental relics, particularly to Hirsau. Both the original colony of monks at Hirsau (founded $c$ 830) and Abbot Hartmut of St Gallen were trained at Fulda (Trithemius 1690: 19; Duft 1969).

\section{THE SAINT IN THE ROOM: MEANING}

Because the book is the life of St Columba and the figure himself is labelled as St Columba, it is most likely that the shrine contains his relics rather than some unspecified other saint. In which case, why is he shown alive and well in front of his own bones? There are two explanations for this rather unsettling concept, one allegorical, the other a belief in praesentia.

An allegorical interpretation is justified because, through its attributes of the shrine, mountain and arch, the artist has elevated the portrait into a liminal image which compresses both time and space. The saint is both alive and dead; simultaneously outdoors and in a church. The saint hovers between these different states and viewers are forced to expand their perception accordingly. The 4th-century writer John Cassian established the fundamental medieval approach to interpreting scripture with four levels of meaning: literal; allegorical; tropological (or moral); and anagogical, relating to eternity (Barton 1998: 161). A literal interpretation relates to an incident in Columba's Life where, secretly watched by one of the brethren, he stood 'on a knoll among the fields praying with his arms spread out towards heaven and his eyes gazing upwards' and flocks of angels came to converse with him. Thereafter the hillock was called Cnoc nan Aingel, the angels' knoll (Sharpe 1995: III-16; Cod Sang 555, p 132-3). Allegorically, this communion with the Divine on a mountain is predicated in the Old Testament by God speaking to Moses on Mount Sinai, as he delivers the Ten Commandments (Exodus 19:18-24). The Ark of the Covenant/shrine with cherubim and mercy seat prompts this allegorical link. In the New Testament it is at Christ's transfiguration on a mountain that God speaks once more, to affirm Christ's divinity (Matthew 17:1-6). The prophet Isaiah (52:7) provides a tropological or moral meaning to the scene, whereby the message from on high is one of peace and good tidings: 'How beautiful upon the mountains are the feet of the messenger who announces peace, who brings good news, who announces salvation, who says to Zion, "Your God reigns", (NRSV). The anagogical or eternal meaning is implied by the saint's continuing physical presence long after his death. So every stage of this interpretation provides a reminder that the saint is a vessel for heavenly communication.

Such a layered response can also be applied to St Augustine's concept of individual spiritual growth as it relates to the whole of human history. He divided time into four states: ante legem (before the Law, from Creation to the Ten Commandments); sub lege (the remainder of the Old Testament); sub gratia (under the grace of Christ) and sub pace (in peace, 
beyond this life, in the resurrection of the body) (Augustine 1955: chapter 31, para 118). This temporal division links the image of Columba's eternal body (sub pace) with Moses just before he receives the commandments (ante legem); Isaiah's 'feet on the mountain' after the Law (sub lege); and Christ's transfiguration, under grace (sub gratia).

The second approach concerns the concept of praesentia (Brown 1981: 1, 3-4, 86-105; Crook 2000: 16-18). In the same way that Christ's risen body was physically present in the host, by the late 5 th century it was believed that the saint was simultaneously present at his grave and resident in heaven. Various inscriptions in churches attest to this, for instance at the tomb of St Martin of Tours: 'Here lies Martin bishop of holy memory, whose soul is in the hand of God, but he is fully present here, made manifest through every grace of miracles'; in Abbot Eigil's church at Fulda was a verse written by Hrabanus Maurus: 'Here the holy hermit Antony is present at the altar ... Here the monk Saba together with Abbott Theodosius are present through vows and pious prayers' (quoted in Crook 2000: 17). This reference would have been known to Abbot Hartmut of St Gallen, previously a student of Hrabanus Maurus at Fulda. For Gregory of Nyssa, proximity to the saint affected all the senses: 'Those who hold the [relics] embrace, as it were, the living body in full flower: they bring eye, mouth, ear, all the senses into play, and then shedding tears of reverence and passion, they address to the martyr their prayers of intercession as though he were present' (Gregory of Nyssa, quoted in Brown 1981: 11).

What makes this picture astonishing is that it expresses the written and theological concept of praesentia in visual form. The only comparison I can find is the literal representation of a miracle of Cuthbert, where his spectral hand emerges from the tomb to heal a paralytic (London, B L Yates Thomson, MS 26, f 83). However, this has quite a different function, simply illustrating a miraculous incident, not witnessing the immanent presence of the saint. Although I can find no record of St Columba making an appearance at St Gallen, Walahfrid Strabo's Life of St Gall, written in the mid-9th century, provides a vivid account of this phenomenon, relating to the patron saint in his church. A man praying to be released from tight manacles spent the night beside St Gall's tomb and was blessed by the sight of a 'venerable white-haired man wearing a chasuble' who saves him (Joynt 1927: 145). A monk who attempted to bleed himself by slitting his vein became infected and was cured by an 'old man standing by him, of serious but serene aspect' (Joynt 1927: 146). The final example has considerable relevance for our image because it connects the presence of St Gall with a sickly supplicant from Scotland. There 'came to the monastery certain men of the Scottish nation (with whom the habit of travelling has now become well-nigh second nature)' and they left behind one of their group who had fallen sick. One night 'in a vision he saw standing beside him an aged man of reverend garb and bearing'. He begged the saint 'I believe I have been kept hitherto for this very purpose that the glory and renown of thy merits may be revealed to the men of thy own race even as they are already known far and wide among these barbarians'. The next day the Scotsman staggered to the shrine and was gradually able to haul himself up, healed (Joynt 1927: 151-2). Here the visual manifestation of continental St Gall is being used to affirm his miraculous powers among a remote audience (in this case Scottish); in a parallel way, the illustration of Columba is being used to alert a less familiar audience on the Continent.

Just as the relics generated the actual presence of the saint, his libellus or Life physically embodied the saint himself. Prudentius, a 4thcentury writer of saints' lives, saw his written texts as a metaphor for the martyrs' scarred, blood-marked bodies (Ross 1995: 327-8). In his Peristephanon IX: 52, he refers to the pricks on the skin of the martyr resembling a wax tablet furrowed by writing (Ross 1995: 338). The skin of the page with its inked letters was the skin of the saint. Prudentius' intense association between the flesh of the martyr and the parchment of the book was well known at St Gallen: the earliest surviving illustrated version of his poem was made in the scriptorium (or possibly at nearby Reichenau) around 900 (Bern Burgerbibliotek, Cod 264). Reading the passio or life of the saint 
aloud took place on the saint's festival, 9 June for St Columba. Reeves observes that Cod Sang 555, with its chapter headings and excessive names redacted, was conveniently tailored for reading out loud (Reeves 1874: xxiii). According to Gregory of Tours, when the passio of a martyr was read, the saint was really there, and a 'sweet scent filled the basilica' (Gregory of Tours, 1885a: 94.359; quoted in Brown 1981: 82) Moreover, Brown observes that 'without a passio the praesentia of the saint lacked weight' (Brown 1981: 82). Thus, St Patroclus of Troyes missed out because he did not have a book written about him: 'The men of that place paid little reverence to this martyr, because the story of his sufferings was not available. It is the custom of the man in the street to give more veneration to those saints whose combats are read aloud' (Gregory of Tours, 1885b: 63.81). So the book was an essential complement to the shrine, both as a sacred artefact in its own right and as the means of recounting the story.

If the book embodied the saint himself, the images enhanced his power. To demonstrate the active role played by the images, Hahn quotes from an illustrated Byzantine saint's life, 'This book contains beautiful images like stars ... eager mediators before the Lord at the time of Judgement'. She adds 'I know of no Western example in which illustrations are part of the book metaphor' (Hahn 2001: 3), but this is what we are seeing in the image of Columba: his image is actively mediating for us. So the portrait, within the book, is simply a reminder to its readers that they are in the presence of the saint himself through holding the book and looking at the picture. The reader becomes an active witness like the monk watching Columba on Iona, or Peter, James and John at the transfiguration.

\section{THE SAINT IN THE ROOM: FUNCTION}

Lastly we may ask what this revenant Columba is actually doing. He stands with raised hands in orans position, on a mountain, in front of an arch, beside an altar displaying his relics. Yeoman (2016: 157-8) reasonably compares the arrangement to that of the 9th- or 10th- century Lotharingian ivory diptych, where one leaf shows a bishop among his choir, possibly officiating the introit at the beginning of the mass (The Fitzwilliam Museum 2000-2018). The other leaf is equally relevant, showing the altar and the backs of the congregation (Liebieghaus 2018). However, our image has two significant differences: there is no chalice and paten upon the altar and St Columba is dressed in an alb (long tunic) and kneelength cowl, the daily house dress of monks since the reforms of Benedict of Aniane in the early 9th century (Goetz 2002: 111). In the ivories the bishop is correctly robed with his chasuble and pallium for performing the mass. Is Columba somehow being demoted? Maureen Miller (2014) describes the many nuances and variations in clerical dress during the reforms of the Carolingian time. In particular she tries to distinguish clerical 'street wear' from liturgical vestments. For performing the mass, there are continuous admonitions and advice for priests to display items of hierarchical significance. However, for daily wear, the main injunctions concern simplicity, humility and modesty (Miller 2014: 12, 15, 19-23). Alcuin gave an important warning to Archbishop Aethelhard of Canterbury who was planning to visit Charlemagne in 801 . Referring to the clerics he says 'Do not let them wear silk or gold clothing in the king's presence; let them go forth in humble attire following the custom of the servants of God' (quoted in Alcuin 1887: letter 230; Miller 2014: 115). Miller's contemporary quotations demonstrate that vestments depend on the occasion. The Hartker Antiphonary of c 900-1000 (Cod Sang 390, f 11) shows St Gall himself likewise clad in a humble alb and cowl where his role is simply to receive a book, not perform some liturgical function. This casual detail of the cowl worn by both saints therefore reinforces the visual expression of praesentia: Columba is not performing the liturgy but communicating directly with his followers in the church through his relics.

The allegorical interpretation described above showed examples of the 'holy man on the mountain' communing with God. In that role Columba would be generically serving as a powerful intercessor but his Vita describes 
a further function which relates the mountain directly to the church, and connects Columba on Iona with his relics at St Gallen. Shortly before his death, Columba 'climbed a little hill overlooking the monastery and stood a while on the top. Standing there, he raised both his hands and blessed the monastery'. This hill is probably the one now known as Cnoc nan Carnan (Sharpe 1995: III-23, no. 409; Cod Sang 555, p 152). With the mountain and its Carolingian architectural setting, the portrait is thus located simultaneously on Iona and at St Gallen, whereby Columba is blessing both places. This is an appropriate coda for the book.

It remains to assess the importance, within the corpus of saints' lives, of this 'earliest portrait of St Columba' as an illustration in his Vita. The St Gallen scriptorium was an industrious engine for the production of saints' lives at this early phase of their evolution. At roughly the same time as Adomnán's book was produced, Notker Babulus wrote a long entry in the 890s about Columba in his Martyrology, under his saint's day, 9 June. This was based on the long recension of Columba's Life, probably the Dorbbéne Codex (Picard 1998: 9). The monastery also produced the lives of the early popes and martyrs (Cod Sang 569); the lives of early Christian, German and Carolingian saints (Cod Sang 577); Benedictine saints (Cod Sang 565); and a miscellany of saints (Cod Sang 563) (Tremp \& Schmuki 2003). Thus, although writing and illustrating the life of Columba was an acknowledgement of the monastery's Irish foundation, by the 9th century there was a great interest, shared across the Carolingian Empire, in writing the lives of many other saints too.

The illustration of early hagiographies is a large field of scholarship exemplified by the work of Wormald (1988), Abou-El-Haj (1997) and Hahn (2001). Although the Columba portrait was first reproduced by Reeves in 1857 (plate 5 facing xxviii), none of these later authors have remarked on it. Paintings of saints' lives appeared first on the walls of churches in Rome, with early northern examples mentioned at Clermont Ferrand in the 5th century and surviving at Müstair from the early 900s (Miller 2014: 11314). One of the earliest well-preserved cycles is on the golden altar of St Ambrose in Milan, made shortly before 859. But these cycles of illustration do not appear in books until the 10th century. The earliest surviving illustrated saint's life in a book is that of St Romanus, one poem in Prudentius' Peristephanon, made at St Gall or Reichenau, around 900 (Bern, Burgerbibliothek Cod 264, ff 122b-148a; Abou-El-Haj 1997: 154). This is shortly followed by cycles on the lives of Kilian of Wurzburg, St Wandrille, and St Agatha during the 10th century (Abou-El-Haj 1997: 154). These illustrations are all based on events in the saints' lives, usually events mentioned in the text. Later illustrated lives, like that of St Cuthbert, start to show posthumous miracles taking place at the tomb. The purpose of these types of narrative image is to enhance the text by generating more vivid emotions among the viewers, encouraging them to engrave the deeds of the saint on their heart, as a model for their own life. When compared with the extensive cycles illustrated by Abou-El-Haj and Hahn (1997: figs 1-206; 2001: figs 1-149), it is clear that our single portrait is not conceived in similar terms. With attributes which are temporally and spatially contradictory, it is not intended to amplify the text at all. It nonetheless has a unique reason to be in this particular volume. Cod Sang 555 is an abbreviated version of Columba's life, specially tailored to appeal to a continental audience. In the text, miracles of Columba are given prominence, for the edification of monks, but whole chapters concerning Irish kings and lesser known laymen have been omitted. The Iona roots are being rubbed out, even literally where names like Columba's maternal grandfather have been further redacted (Picard 1998: 8-9). This volume and this illustration are specifically targeted towards readers at St Gallen, where the image demonstrates they will still experience the living presence of St Columba, both while they hold the book and stand beside his relics in $\mathrm{St}$ Gallen church.

\section{NOTES}

1 Digital enhancement reveals that the very faint letters on the top left of the page, below 
the brown stain, are probatio pennae, a Latin hexameter containing all the letters of the alphabet: Adnexique globum zephyri freta kanna secabant, roughly translated as 'The ash-grey straits cut through the bulk of the Zephyrium [mountains] attached [to Sicily]'. This exercise is found elsewhere in St Gallen manuscripts, for instance Cod Sang 111, $\mathrm{p}$ 352. The horizontal line of writing above the shrine is currently indecipherable, may be mirror-inverted, or a palimpsest. I am grateful for assistance with deciphering the letters to Franziska Schnoor.

2 Coinciding with the publication of this article, St Gallen Stiftsbibliothek has produced an exhibition which places the Irish heritage of the abbey, including Cod Sang 555 in its historical context (Dora \& Schnoor 2018).

3 Walahfrid was abbot of nearby Reichenau 842-9 but was closely involved with St Gallen, writing the lives of St Gall and Abbot Othmar, while dedicating his book on gardening, Hortulus, to Abbot Grimald (841-72) of St Gallen. The earliest text of Blathmac's poem is found at $\mathrm{St}$ Gallen, Cod Sang 899, second half of the 9th century.

\section{ACKNOWLEDGEMENTS}

I would like to thank Peter Yeoman for introducing me to this subject, John Crook for his advice on shrines, George Henderson and Jane Hawkes for help with iconography, and Aaron Thom and Peter Yeoman for digital manipulation.

\section{REFERENCES}

Abou-El-Haj, B 1997 The Medieval Cult of Saints: formations and transformations. Cambridge: Cambridge University Press.

Alcuin 1887 Monumenta Germaniae Historica, Epistolae, 4. Epistolae Karolini aevi II. Berlin.

Anderson, A O 1990 Early Sources of Scottish History, 2 vols. Stamford: Paul Watkins.

Appleby, D 1995 'Rudolph, Abbot Hrabanus and the ark of the covenant reliquary', American Benedictine Review 46: 419-43.
Augustine of Hippo 1955 Enchiridion: On Faith, Hope, and Love. Outler, A C (ed. and trans), Dallas. http://www.tertullian.org/ fathers/augustine_enchiridion_02_trans.htm \#C31. Accessed 1 October 2017.

Bagnoli, E, Klein, H A, Mann, C G \& Robinson, J 2011 Treasures of Heaven: Saints, Relics and Devotion in Medieval Europe. London: British Museum Press.

Bannerman, J 1993 'Combara Coluim Cille and the relics of Columba', Innes Review 44(1): 14-47.

Barton, J (ed.) 1998 The Cambridge Companion to Biblical Interpretation. Cambridge: Cambridge University Press.

Bresslau, H (ed.) 1932 'Miracula Sancti Columbani', Monumenta Germaniae Historica, SS XXX, 2, 993-1015.

Brown, P 1981 The Cult of Saints: its Rise and Function in Latin Christianity. Chicago: University of Chicago Press.

Bruce-Mitford, R L S 1969 'The Art of the Codex Amiatinus. Jarrow Lecture 1967', Journal of the British Archaeological Association 32: $1-25$.

Crook, J 2000 The Architectural Setting of the Cult of Saints in the Early Christian West c 300 1200. Oxford: Clarendon Press.

Dewald, E T 1922 'The appearance of the horseshoe arch in Western Europe', American Journal of Archaeology, Second Series. Journal of the Archaeological Institute of America, XXVI, no. 3: 316-37.

Dora, C \& Schnoor, F (eds) 2018 The Cradle of European Culture: Early medieval Irish book art. St Gallen: Klosterhof.

Farmer, D H 1980 The Oxford Dictionary of Saints. Oxford: Clarendon Press.

Freeman, A \& Meyvaert, P 2001 'The Meaning of Theodulf 's Apse Mosaic at Germigny-desPrés’, Gesta 40(2): 125-39.

Freeman, C 2011 Holy Bones, Holy Dust: how relics shaped the history of medieval Europe. Newhaven: Yale University Press.

Goetz, H W 2002 Leben im Mittelalter, vom 7. bis zum 13. Jahrhundert. Munich: Beck.

Gregory of Nyssa 1844 Encomium on Saint Theodore, Patrologia Graecia. Migne, J-P (ed.). Paris 1844 onwards, 46, 740 b. 
Gregory of Tours 1885a 'Liber in gloria confessorum', in Krusch, B (ed.) Gregorii episcopi Turonensis, Miracula et opera minora. Hanover: Hahn. Monumenta Germaniae Historica: Scriptores Rerum Merovingicarum.

Gregory of Tours $1885 \mathrm{~b}$ 'Liber in gloria martyrum', in Krusch, B (ed.) Gregorii episcopi Turonensis, Miracula et opera minora. Hanover: Hahn. Monumenta Germaniae Historica: Scriptores Rerum Merovingicarum.

Hahn, C 2001 Portrayed on the Heart: narrative effect in pictorial lives of saints from the tenth through the thirteenth century. Berkeley: University of California Press.

Joynt, M 1927 The Life of St. Gall. Lampeter: Llanerch Publishers.

Lubke, H (ed.) 1965 Karl der Grosse: Werk und Werkung. Aachen: Council of Europe.

Meehan, B 2005 'Book Satchels in Medieval Scotland and Ireland', in Crone, A \& Campbell, E A Crannog of the First Millennium $A D$, excavations by Jack Scott at Loch Glashan, Argyll, 1960, 85-92. Edinburgh: Society of Antiquaries of Scotland.

Miller, M C 2014 Clothing the Clergy: virtue and power in medieval Europe, c 800-1200. Ithaca: Cornell University Press.

Notker Balbulus 1844-65 'Martyrologium', in Migne, J-P (ed.) Patrologiae Cursus Completus, Series Latina, 131, cols 1025-164; June 9, cols 1101-3 para 1. Paris.

Odo of Cluny 1844-65 'Collationes, ii. 28', in Migne, J-P (ed.) Patrologiae Cursus Completus, Series Latina, 133, col 573. Paris.

Picard, J-M 1998 ‘Adomnán's Vita Columbae and the cult of Colum Cille in Continental Europe', Proceedings of the Royal Irish Academy 98C: 1-23.

Prudentius 1953 Works, 2 vols, Loeb Classical Library, Thomson H J (ed. and trans). London: Heinemann.

Quast, D 2012 Das Merowingerzeitliche Reliquienkästchen aus Ennabeueren. Mainz: Verlag des Römisch-Germanischen Zentralmuseums.
Reeves, W 1857 The Life of St Columba, Founder of Hy. written by Adamnan. Dublin and Edinburgh: Edmonston \& Douglas. https:// archive.org/details/lifeofsaintcolum00 adamuoft. Accessed 17 February 2018.

Richter, M 2008 Bobbio in the Early Middle Ages. Dublin: Four Courts Press.

Ross, J 1995 'Dynamic Writing and Martyrs' Bodies in Prudentius' Peristephanon', Journal of Early Christian Studies 3(3). Fall: 325-55.

Sharpe, R (intro and trans) 1995 Adomnán of Iona, Life of St Columba. London: Penguin.

Smith, J 2015 'Les reliques et leurs étiquettes', in Andenmatten, B, Ripart, L, Mariaux, P-A \& Brero, $\mathrm{T}$ (eds) L'abbaye de Saint-Maurice d'Agaune, 515-2015, 221-57. Gollion: Editions Infolio.

Stokes, W (ed.) 1877 Three Middle-Irish Homilies on the Lives of Saints Patrick, Brigit and Columba. Calcutta.

Stokes, W (ed. and trans) 1887 The Tripartite Life of St Patrick, 1-207. London: HMSO.

Stückelberg, E A 1902-8 Geschichte der Reliquien in der Schweiz, 2 vols. Zurich: Schweizerische Gesellschaft für Volkskunde.

Tremp, E \& Schmuki, K 2003 Geschichte und Hagiographie in Sanktgaller Handschriften: Katalog durch die Austellung in der Stiftsbibliothek St Gallen 2002-3. St Gallen: Verlag am Klosterhof.

Trithemius, J 1690 Annales Hirsaugienses I. St Gallen.

von Euw, A 2008 Die St. Galler Buchkunst vom 8. bis zum Ende des 11. Jahrhunderts, Band I: Textband, St Gallen (Monasterium Sancti Galli, Bd. 3). St Gallen: Verlag am Klosterhof.

Wormald, F 1988 'Some illustrated manuscripts of the Lives of Saints', Bulletin of the John Rylands Library, Sept 1952, 35, no. 1: 248-66. Reproduced in Alexander, J J G, Brown, T A \& Gibbs, J (eds) Collected Writings II, Studies in English and Continental Art of the later Middle Ages, 43-56. London: Harvey Miller.

Yeoman, P 2016 'A house-shaped shrine in a Carolingian setting, as depicted in the oldest image of St Columba in Cod Sang 555', Proc Soc Antiq Scot 146: 153-65. https://doi. org/10.9750/PSAS.146.1215. 
MANUSCRIPTS LISTED BY LIBRARY APART FROM COD SANG, WHICH REFERS TO ST GALLEN, STIFTSBIBLIOTHEK. WEB SITES ALL ACCESSED 1 OCTOBER 2017 UNLESS OTHERWISE STATED.

Bern, Burgerbibliothek, Cod 264 Prudentius, Carmina. https://www.e-codices.unifr.ch/en/ list/one/bbb/0264.

Cambridge, Trinity Hall, MS 1, Thomas Elmham Historiae Abbatiae S. Augustini. https://www. trinhall.cam.ac.uk/library/the-enthronementof-the-archbishop-of-canterbury-and-a-trinityhall-manuscript/. Accessed 4 June 2018.

Cod Sang 22, St Gallen, Stiftsbibliothek, Cod Sang 22: Golden Psalter. https://www.e-codices. unifr.ch/en/list/one/csg/0022.

Cod Sang 23, St Gallen, Stiftsbibliothek, Cod Sang 23: Folchart Psalter. https://www.e-codices. unifr.ch/en/list/one/csg/0023.

Cod Sang 111, St Gallen, Stiftsbibliothek, Cod Sang 111: Copy of Jerome's commentary on chapters 14-18 of the Book of Isaiah. https:// www.e-codices.unifr.ch/en/list/one/csg/0111.

Cod Sang 286, St Gallen, Stiftsbibliothek, Cod Sang 286: Hrabanus Maurus De institutione clericorum. https://www.e-codices.unifr.ch/ en/searchresult/list/one/csg/0286.

Cod Sang 390, St Gallen, Stiftsbibliothek, Cod Sang 390: Hartker Antiphonary, Antiphonarium officii. https://www.e-codices.unifr.ch/en/list/ one/csg/0390.

Cod Sang 555, St Gallen, Stiftsbibliothek, Cod Sang 555: Vita sancti Columbae. https:// www.e-codices.unifr.ch/en/list/one/csg/0555.

Cod Sang 563, St Gallen, Stiftsbibliothek, Cod Sang 563: Vitae of ancient Roman and Franconian saints. https://www.e-codices. unifr.ch/en/list/one/csg/0563.

Cod Sang 565, St Gallen, Stiftsbibliothek, Cod Sang 565: Lives of the Benedictine Saints. https://www.e-codices.unifr.ch/en/list/one/ csg/0565.

Cod Sang 569, St Gallen, Stiftsbibliothek, Cod Sang 569: Vitae of early Christian popes and martyrs. https://www.e-codices.unifr.ch/en/ list/one/csg/0569.

Cod Sang 577, St Gallen, Stiftsbibliothek, Cod Sang 577: «Passionarium novum»: Lives of early Christian, early German and Carolingian Saints. https://www.e-codices.unifr.ch/en/list/ one/csg/0577.

Cod Sang 731, St Gallen, Stiftsbibliothek, Cod Sang 731: Lex Romana Visigothorum, Lex Salica, Lex Alamannorum. https://www. e-codices.unifr.ch/en/list/one/csg/0731.

Cod Sang 855, St Gallen, Stiftsbibliothek, Cod Sang 855: Grammatica / De rhetorica / Institutiones II / De natura rerum / Miscellaneous; drawings. https://www.e-codices.unifr.ch/en/ list/one/csg/0855.

Cod Sang 899, St Gallen, Stiftsbibliothek, Cod Sang 899: Poetry Manuscript. https://www.ecodices.unifr.ch/en/list/one/csg/0899.

Cod Sang 1092, St Gallen, Stiftsbibliothek: Plan of Saint Gall. https://www.e-codices.unifr.ch/en/ list/one/csg/1092.

Dublin, Trinity College, MS 52, Book of Armagh

London, British Library, Yates Thomson MS 26, Life of St Cuthbert. http://www.bl.uk/ manuscripts/FullDisplay.aspx?ref=Yates_ Thompson_MS_26.

Munich, Bayerische Staatsbibliothek, Clm 14000, Evangeliar, Codex Aureus. http://daten. digitale-sammlungen.de/ db/0005/bsb 00057171/images/index. html? seite $=35 \& \mathrm{f}$ $\mathrm{ip}=193.174 .98 .30$.

Schaffhausen Stadtbibliothek, Gen 1: Adamnanus de Iona, Vita Columbae. https://www.ecodices.unifr.ch/en/list/one/sbs/ppp1.

Trier, Stadtbibliothek, HS171/1626, Gregory leaf. https://en.wikipedia.org/wiki/Registrum_ Gregorii.

Utrecht, Universiteitsbibliotheek, MS 32, Utrecht Psalter. http://psalter.library.uu.nl/ page $\mathrm{p}=13 \&$ res $=1 \& \mathrm{x}=0 \& \mathrm{y}=0$.

Zürich, Zentralbibliothek, MS C 12 St Gallen Psalter. https://www.e-codices.unifr.ch/en/ searchresult/list/one/zbz/C0012.

\section{OTHER ONLINE SOURCES}

Duft, J 1969 'Hartmut', in Neue Deutsche Biographie 8 (online version). https://www. deutsche-biographie.de/gnd 102475717. html\#ndbcontent. Accessed 12 February 2018.

The Fitzwilliam Museum 2000-2018 An Archbishop among his choir. http://webapps. 
fitzmuseum.cam.ac.uk/explorer/index. php?oid=31579. Accessed 1 October 2017.

Liebieghaus 2018 Middle Ages. http://www. liebieghaus.de/en/middle-ages. Accessed 1 October 2017.

MacLeod, D 2011 The Bayeux Tapestry: Unpicking the Past. http://www.bbc.co.uk/history/british/ normans/bayeux_tapestry_gallery_04.shtml. Accessed 23 February 2018.

NRSV (Bible Gateway, New Revised Standard Version) 1989. https://www.biblegateway. com/versions/New-Revised-StandardVersion-NRSV-Bible. Accessed 1 October 2017.
St Gall Plan 2012. http://www.stgallplan.org/en/ index_plan.html. Accessed 1 October 2017.

St Gall Plan 2012 Architecture. http://www. stgallplan.org/StGallDB/architectures/public_ english_full/83. Accessed 23 February 2018.

Trinity Chapel glass, Canterbury. http://1450v. alamy.com/450v/d8jkkd/medieval-c13thstained-glass-in-the-trinity-chapel-ofcanterbury-cathedral-d8jkkd.jpg. Accessed 1 October 2017.

Winchester Cathedral 2018 'Morley Library'. http://www.winchester-cathedral.org.uk/ gallery/the-morley-library/. Accessed 1 October 2017. 